\title{
The Formative Stage of the Christ Apostolic Church (C.A.C) (Nigeria), 1917-1943
}

\author{
Dr. Jegede, Gabriel Gbenga \\ Faculty of Arts \\ Ekiti State University, P.M.B 5363 \\ Ado-Ekiti, Nigeria \\ E-mail: ggjegede@gmail.com
}

\begin{abstract}
The outbreak of influenza epidemic in Nigeria as from the second decade of the 20th century coupled with the worldwide economic recession within the same period forced the missionary agents of the mainline churches to abandon their mission stations. With their departure to their native countries, Christians in SouthernWestern Nigeria became stranded due to lack of spiritual leadership. This scenario forced them to form prayer groups that could assist in their spiritual needs at that critical period in their historical experience. Prominent among the prayer groups was Egbe Okuta Olowo Iyebiye (The Precious Stone Society). The group led by J.S. Sadare of Our Saviour's Anglican Church, Ijebu-Ode became the catalyst for the emergence of Pentecostalism in Nigeria, from 1917-1943. This paper traces the series of stages and events that led to the formation of the Christ Apostolic Church (C.A.C). it expounds the impact of the Faith Tabernacle Movement (Philadelphia, USA), the magazines called: Sword of The Spirit and Riches of Grace. It notes the roles of the Apostolic Church (Britain) in shaping the spiritual directions of the progenitors of the C.A.C. The paper which makes use of the descriptive historical method acknowledges the contributions of Apostle Ayo Babalola vis-à-vis the Oke-Oye revival in the events that culminated in the formation of the C.A.C. The paper concludes that the C.A.C. could be regarded as the leadinglight of Pentecostalism in Nigeria.
\end{abstract}

Key Words: Christ Apostolic Church, Nigeria, history, formative, stage.

\section{Introduction}

\section{The Beginning of The Church}

The emergence of the Christ Apostolic Church (C.A.C) on the religious landscape of Nigeria could be traced to the consequences of the nation-wide outbreak of epidemic in the second decade of the 20th century ${ }^{1}$. Consequent upon the outbreak of the influenza pandemic in about 1918, many of the churches, schools and several public institutions were closed. The missionary agents decided to leave Nigeria in large numbers. The Christians in Nigeria were therefore abandoned without the needed spiritual attention. Given the scenario, the work of evangelism was left in the hands of few African Church leaders who were compelled by the 
unforeseen situation to empathize with their brethren. Isichei sheds more light on the prevailing situation at that time:

... afflicted by epidemic (influenza, small pox and plague), famine and world economic depression; scores of people collapse on the roads, many chose shady trees under which to lie down and die. I visited some houses where every member was lying dead ${ }^{2}$.

Besides, Peel a Sociologist of Religion who carried out extensive research in South Western Nigeria, explains the prevailing mood at that time in the following words:

The Yoruba were afflicted with series of natural disasters influenza, plagues, famines and depression following the rapid growth of a monetary economy- these demanded religious interpretations. Theirs usually severe nature meant that the traditional religion, already fast declining, was inadequate to explain or relieve them, and Christianity (which has every sign of the permanence and was generally associated with what the young and ambitious felt desirable) was so used. The God whom the Christians preached had sent the disasters as a punishment but the Christian religion provided a way out ${ }^{3}$.

The epidemic which was called lùkúlùkút in Ekitiland killed thousands of people and rendered many people physically incapacitated. A foremost Catholic Priest and Chronicler of Ekiti history, Oguntuyi, paints a horrible picture of the epidemic thus:

...in October, 1918, an epidemic influenza broke out in Ekiti. Unfortunately, the cause was attributed to witchcraft and the anger of the gods. Many domestic animals were slaughtered to satisfy the blood-thirsty witches and wizards. All over Ekiti, the remedies believed by the people to be always efficacious were applied..., but the situation grew worse... The epidemic raged fiercely for about six months and thinner down the population. The dead were not mourned. Many were not even buried ${ }^{5}$.

A notable Nigerian church leader who rose to the challenge of the devastating crisis was $\mathrm{Mr}$. J.S. Sadare of Our Saviour's Anglican Church, Ijebu-Ode. In fact, in c. 1918, during his sojourn in Ibadan as a staff of the Railway Corporation, he came in contact with a praying group which was called "Egbe Okuta Olowo Iyebiye” (i.e. The Precious Stone or Diamond Society) 6 . He was very close to the prayer group during the period of the epidemic. 


\section{The Spiritual Revival at Ijebu-Ode}

On his return to Ijebu-Ode, he went into fellowship with another group of adherents of the Anglican Church in the town who had organized a revival service that was meant to enhance their spiritual fortification against the influenza epidemic. Initially, the group enjoyed the support of the top echelons of the Ijebu-Ode Anglican Church who were elated and impressed by the high level of spirituality among its members at that critical and trying period. It is worthy of note that in the prayer group at Our Saviour's Anglican Church, Ijebu-Ode, there was a school teacher, Miss Sophia Odunlami, who later got married to Mr. J.L. Ajayi. She was said to be spiritually potent and thus became a wonderful instrument for spiritual healings and deliverance. In her highly fruitful and rewarding prophecy, she revealed that "only rain-water mixed with lime could effectively cure the epidemic"?

There was an upsurge in the membership of the prayer group as Odunlami's prescription became very potent and effective in combating the epidemic scourge. Given this realization, Our Saviour's Anglican Church, Ijebu-Ode was practically turned to a healing centre for those afflicted with the influenza scurge from the entire Yorubaland and its neighbours ${ }^{8}$. This development led to a phenomenal growth and development of Christianity in South-Western Nigeria as Oshun reveals:

This was an opportunity to give vent to the group's faith in healing and in prevailing prayer. This was a new dimension to Christianity. The outcome for the group was a sharp increase in its membership as well as its growing popularity. ---The membership was seemingly drawn from among the down-trodden or the outcasts. The type of faithreaction registered at Ijebu-Ode, in confronting the menace of the pandemic was similar to the faith-reaction of the Faith Tabernacle groups in Philadelphia (US) and Accra (Ghana) ${ }^{9}$.

The first reaction of the Anglican Church to the spiritual proclivities of the Diamond Society was favourable and encouraging. It (the Anglican Church) supported the timely spiritual revival because it encouraged many people to become Christians. It also resulted in meaningful membership boost for the Anglican Church at Ijebu-Ode.

However, the initial romance and honeymoon soon turned sour. The spiritual revival championed by Sophia Odunlami was soon viewed as being diametrically opposed to the 
orthodox doctrinal practices of the church ${ }^{10}$. Even Sophia herself was considered to be probably acting under the spiritual ecstasy and perversive influence of some demonic forces. Fatokun reveals further the impact of the spiritual proclivities of Odunlami vis-à-vis the Precious Stone Society:

Shadare was forced to resign his seat at the synod. Similarly all teachers who were members of the society were asked either to renounce their membership with the "fanatical group" or else lose their jobs and also withdraw their children from the Anglican Schools. The leadership and members of the Precious Stone Society felt unjustly victimized and persecuted, and so they left the Anglican Church, and started holding meetings as a district church-- In 1923, all branches of Precious Stone Society unanimously agreed to affiliate with the Faith Tabernacle Congregation, a holiness movement with headquarters at Philadelphia, U.S.A ${ }^{11}$.

The affiliation with the foreign faith group was facilitated through the efforts or assistance of David Odubanjo ${ }^{12}$ who heads its Lagos branch. In spite of the negative dispositions of some people towards the "Diamond Society", it continued to blossom.

\section{Affiliation with The Faith Tabernacle Movement}

What served as a turning point in respect of the spiritual awakening championed by members of the Diamond society at Ijebu-Ode was the influence of a magazine called Sword of The Spirit. It was published by "The Faith Tabernacle" which was based in Philadelphia (U.S.A) ${ }^{13}$. The Faith Tabernacle made it a duty to distribute free copies of its magazine (Sword of the Spirit) to its numerous subscribers in Nigeria ${ }^{14}$.

Given the similarities in the belief of the Faith Tabernacle and that of the Diamond Society in respect of healings through prayer, baptism of the holy spirit and adult baptism as against infant baptism, there began a form of collaboration between the two groups ${ }^{15}$. The shared beliefs of both the Diamond Society and The Faith Tabernacle were not compatible with that of the Anglican Church, hence members of the Diamond Society could not stay there and still remain relevant. To aggravate the incompatibility of the Diamond Society and the Anglican Church, Mr. S. Sadare refused to abide by the decision of the Anglican Synod of Ijebu-Ode in 1920 to release his children for early or infant baptism ${ }^{16}$. He was rigid and unwavering in hi 
stance that he had been warned against a compromise with such practice by the Holy Spirit in his spiritual encounters and experiences.

Consequent upon the reluctant of members of the Diamond Society to abandon its position in favour of the views of the Anglican Church on healings and baptism, Sadare and other members of his prayer group were excommunicated from the Anglican Church. Also, with its belligerent posture, the Diamond or Precious Stone Society left the church and affiliated officially with the Faith Tabernacle Movement in Philadelphia (USA).

By 1922, the FTM was already institutionalized in Nigeria with branches in Lagos, Kaduna, Kano, Ilesa, Zaria, Jos, Minna Ijebu-Ode ${ }^{17}$, etc. The movement was further strengthened when many of its leaders in Nigeria were ordained by proxy from $1923-1925^{18}$. Beneficiaries of the ordination were: J.S. Sadare (Ijebu-Ode), J.A. Babatope (Ilesa), S.A. Mensah (Kaduna), G.L. Macaulay (Zaria), G.S. Ogunji (Jos), Pastor Epelle (Umuahia) and to crown it all Pastor Odubanjo (Lagos) was appointed as the General Overseer ${ }^{19}$ (G.O) of the F.T.M. in the country.

As a prolific writer, Pastor Odubanjo contributed greatly to the success of the FTM in Nigeria through his monthly circular letters. Such correspondence cemented the bound of unity within the ranks and files of the movement. Essential information concerning members and leaders got easily circulated to all the nooks and crannies of the country through the instrumentality of the FTM News cum Odubanjo's letters.

1926 marked a turning point in the relationship between FTM (Philadelphia) and its Nigerian affiliate as the Principal was bedeviled by a serious crisis in which Pastor Clarke was a notable actor ${ }^{20}$. Also, involved in the misunderstanding were the other top echelons of FTM in Philadelphia. So bad were the irreconciliable differences of the belligerent groups or parties that Pastor Clarke decided to part ways with FTM and opted to establish his own separate church.

While the confusion and crisis were going on, Odubanjo inadvertently came in contact, in the course of his numerous correspondence, with a different Christian religions group called "Faith and Truth Temple" (FTT) which had its headquarters at Toronto in Canada ${ }^{21}$. As a coincidence, at the time of his discovery, the authority of FTT had concluded plans to send some missionary agents to Upper Volta. He cashed in on the opportunity by requesting them to pass through Nigeria, on a visit, before going to their main destination. 
As requested by Pastor Odubanjo, the agents of F.T.T led by Rev. C.R. Myers paid a visit to members of the Lagos branch of F.T.M. Unfortunately, their adventure was met with fatal consequences as two of the missionary agents died in Lagos of malaria fever. Besides, Myers came back to Lagos from Upper Volta in abject poverty. To add to his frustrations, he lost both his wife and his child and there also developed a frosty relationship between him and his principals at the headquarters of the F.T.T in Canada.

\section{The Oke-Oye Revival of 1930}

The FTM came into prominence in 1930 given the epoch-making events that inadvertently resulted from its delegate conference held at Ilesa in the year under reference. The historic revival after the conference came into being as a result of the spontaneous response to the miraculous feat of Prophet Ayo Babalola who was a delegate at the conference ${ }^{22}$. He stunned participants at the event and people in the host community when he miraculously raised to life a dead man that was being carried to a cemetery for burial. Prof. Oshun gives an eloquent testimony to this:

Babalola had accosted some people on a funeral procession and had requested that the corpse be lowered down. After this, he prayed on the corpse shouting the name of Jesus thrice and ringing his bell at the same time. On the third occasion and to the amazement of all present, the dead man, later recognized as Mr. Obi Ogundipe was revived. Instantly, there was spontaneous jubilation and excitement all over the place which drew the attention of the leaders inside the church to the development outside ${ }^{23}$.

The miraculous feat brought the delegate conference to a sudden closure. Instead the growing crowd of enthusiastic Christians started a revival inadvertently. Within a very short time (even with the poor system of communication at that time), the news of the revival at Ilesa spread to all the nooks and crannies of Ondo, Ekiti, Igbomina, Oyo, Ogun and Benin, among others. According to Ayegboyin \& Ishola, "the heavy throng of people cleared the bushy crusade

ground with their bare feet" ${ }^{\text {" } 4}$. The unprecedented responses were far beyond the imagination of members of the F.T.M.

Given the fact that the number worshippers at the revival increased daily in geometric progression, river Oye which was very close to the revival ground was consecrated and 
symbolically used to solve various ailments and spiritual problems. In fact, it was reported that an avalanche of patients in the hospital discharged themselves or were discharged by their family members ${ }^{25}$ against the instance of the hospitals managements, and carried to the venue of the revival for miraculous healings. The mass movement of patients from the government hospital infuriated the District Officer who accused Apostle Ayo Babalola and his followers of sabotage.

Shortly after the Oke-Oye revival, Babalola also incurred the wrath the colonial administration for "forcefully making people accused of witchcraft to confess" 26 . In addition, members of the FTM were accused of incitements against the colonial government ${ }^{27}$. The specific accusation had to do with the group's preachings against the use of medicine and preference for absolute faith healing. There was also a strong insistence by the government that the Oye river being used for healing purposes was highly unhygienic and could trigger serious health crisis in the whole of South-Western Nigeria.

In furtherance of the belligerent postures of the colonial administration, some leaders of the F.T.M, including Babalola were detained severally. They were equally arraigned before the court on spurious allegations ${ }^{28}$. To clip the wings of the F.T.M and to water down their reputation, the colonial Administration issue stern warnings against the consecration of water for healings and the practice of keeping residents awake by vigils and open-air services. The climax of the strained relationship between the government and members of the F.T.M was the arrest of Babalola at Otuo in the first quarter of 1932 and his imprisonment in Benin for about six months.

\section{Panacea to Hostilities and Second Affiliation}

Given the open display of hostilities by the colonial governments. In order to abate the spate of the attendant persecutions by the agencies of government, leaders of the F.T.M deemed it expedient to seek for foreign supports through affiliation with a British Church that could get the listening ears of the top echelon of the government. To achieve this, Pastor D.O. Odubanjo of the Lagos Assembly of the Faith Tabernacle who had been in regular contact with the Apostolic Church in Bradford, Britain, introduced the official magazine of the Apostolic Church, Riches of Grace to the F.T.M members. After a through analysis and deep study of 
magazine, members were convinced that the Apostolic Church have doctrines and beliefs that were compatible with those of the F.T.M.

As a corollary to the above, and following an appeal by members of the Faith Tabernacle in Nigeria, the Apostolic Church in Bradford sent three missionary agents: D.P Williams, A. Tumbull and W.J. Williams to make very formal its affiliation with the F.T.M ${ }^{29}$. After a deep and broad discussion, a memorandum of agreement cum understanding was signed with the British Apostolic Church (B.A.C). Consequently, the Faith Tabernacle members henceforth adopted the name "Apostolic Church".

In 1932, BAC sent two missionary agents to Nigeria on permanent basis. Their first task was to normalize the strained relationship between members of Faith Tabernacle and the colonial administration ${ }^{30}$. After the truce initiated by the resident pastors from Britain, the colonial government changed its hitherto hostile posture towards members of the Faith Tabernacle and became friendly. The new development facilitated or led to the release of Apostle Joseph Ayo Babalola from prison.

\section{Disagreement Between British Apostolic Church (BAC) and Apostolic Church Nigeria $(\mathrm{ACN})$}

The honeymoon between the B.A.C and A.C.N was shortlived. Few years after the affiliation, the duo disagreed sharply over the insistence of the white British missionaries on the use of medicine, notably quinine ${ }^{31}$. The B.A.C. agents held tenaciously to their position that there was nothing wrong in taking curative and preventive drugs so as to protect themselves from the fatal malaria parasites.

The top echelon of the A.C.N such as Pastors Akinyele, Esinsinade, Odubanjo and Babalola, among others were terribly frustrated by the rigid stance of B.A.C missionaries under the leadership of George Perfect ${ }^{32}$. Nevertheless, some members of the F.T.M in A.C.N decided to stick to their own position on the sanctity of divine healing. Specifically, in 1939, there was a schism which arose from the controversy. The aftermath effect was that those who were vehemently opposed to the use of drugs left the fold and began their own separate church under

the nomenclature: Nigerian Apostolic Church (N.A.C) ${ }^{33}$. Others who pitched their tents with the British missionary agents decided to use the name: The Apostolic Church (T.A.C) ${ }^{34}$. 
Given the growth and development of the N.A.C, especially when it spread its tentacles or influence beyond the shores of Nigeria, the nomenclature (N.A.C) became highly inappropriate. Later, there were pressures from members outside the country on the need to drop "Nigeria" in favour of a nomenclature that would give the church a universal appeal ${ }^{35}$. Consequently, in February 1940, the name of N.A.C was changed to United Apostolic Church (U.A.C).

However, after the adoption of the nomenclature U.A.C, members of the church came to the realization of the obvious fact that the acronym was the same as that of a trading firm in south-western Nigeria, that is: the United African Company (U.A.C). In fact, there was the strong fear or apprehension that such similarity in names would certainly confuse members of the public and government. To solve the problem, the church decided again to change its name to: Christ Apostolic Church (C.A.C) in $1941^{36}$. The new name was given a legal zeal or teeth with the official registration in $1943^{37}$. Later, the church began to share the name with another agency of government, the Corporate Affairs Commission.

\section{Conclusion}

The foregoing discussion deals with the formative stage of the Christ Apostolic Church (C.A.C) in Nigeria. The institutionalisation of the church in some other parts of Yorubaland could be attributed partly to the efforts of Apostle Ayo Babalola and Pastor J.A. Babatope, given their exploits shortly after the Oke-Oye revival at Ilesa in 1930.

In fact the intimidating presence of the mainline churches in Nigeria before the emergence of the C.A.C did not preclude it from making the South-Western Nigeria one of its strongholds. As a result of its ubiquitous presence in all the nooks and crannies of the communities in southern Nigeria by 1943, coupled with the teeming population of adherents, the C.A.C could be regarded as the fastest growing Pentecostal Church within the scope or period under examination. Besides, its pioneering efforts with regard to the entrenchment of Pentecostalism in Nigeria is equally not in doubt.

\section{Notes and References}

1. S.G.A. Adegboyega, A Short History of The Apostolic Church, (Ibadan, Roseprint Press Limited, 1978), P. 1; E. Isichei, A History of Nigeria, (London, Longman Group Limited, 1984), P. 462. 
2. E. Isichei, A History of Christianity in Africa from Antiquity to the Present (New Jersey, William .B. Eerdmans Publishing Company, 1995), P. 280; R.C. Mitchell," Religious Protest and Social Change: The Origins of The Aladura Movement in Western Nigeria", in R. Rotberg \& A. Mazni (eds), Protest and Power in Black Africa, (New York, Oxford University Press, 1970), P. 481.

3. J.D.Y. Peel, Aladura: A Religious Movement Among The Yoruba, (London, Oxford University Press, 1968), P. 292.

4. The nomenclature "lukuluku" (an onomatopoeic) was given to the influenza epidemic of the second and third decades of the 20th century in most towns in Ekitiland due to its attendant killing en-masse and by sudden strokes.

5. A. Oguntuyi, History of Ekiti from The Beginning to 1939, (Ibadan, Bisi Books Company Limited, 1979), P. 123.

6. T. Adamolekun, "Christianity in African Context", in S.I. Ogunsakin - Fabarebo and O. Arowolo (eds.), Foundation Themes in Religion, (Akure, Don Boscos Press Limited, 2001), P. 132.

7. P.A. Adebiyi, History of Christianity in Ekitiland, 1893-1973, (Lagos, C.S.S. Limited, 2003), P. 131.

8. $\quad$ S.G.A. Adegboyega, A Short History... P. 7.

9. C.O. Oshun, "Origins of Christ Apostolic Church, Nigeria: A Critical Assessment of An African Aladadura-Apostolic-Pentecostal Church, 1918-1959”. Being the text of a paper presented to an International Religious Conference on the origins of Christ Apostolic Church. The First Pentecostal Churches in Nigeria and Ghana Jointly organized by The Centre for World Christianity (CWC) of the New York Theological Seminary (NYTS), Joseph Ayo Babalola University (JABU), Ikeji-Arakeji, Osun State, Nigeria, and The Institute for Disaporan and African Culture (TIDAC), Joseph Ayo Babalola University, 6th - 8th August; 2012, P. 5.

10. S.G.A. Adegboyega, A Short History... P. 8.

11. S.A. Fatokun, "The Apostolic Church Nigeria: The Metamorphosis' of Indigenous Prophetic - Healing Movement into a Classical Pentecostal Denomination”, in S.A. Fatokun (ed.) Christianity and African Society, (Ibadan, Bookwright Publishers (Nigeria) 2013), P. 75.

12. S.J. Komolafe, The Transformation of African Christianity, (Carlisle, Longham Monographs, 2013), P. 103.

13. J.D.Y. Peel, Aladura: A Religious Movement Among the Yoruba, (New York, O.U.P, 1968), P. 61.

14. D. Ayegboyin \& S.A. Ishola, African Indigenous Churches: An Historical Perspective. (Lagos, Greater Heights Publications Limited, 1999), P. 66.

15. E.H.L. Olusheye, A Short History of The Christ Apostolic Church, (Ibadan, IBI Press and Publishing Company, 2000), P. 30. 
16. H.W. Turner, History of The African Independent Church, (London, Oxford University Press, 1967), pp. 4-5.

17. D. Ayegboyin \& S.A. Ishola, P. 67.

18. P.A. Adebiyi, P. 133.

19. Brochure of The Apostolic Church, Ilesa on Late Pastor J.A. Babatope, 1st African Superintendent - The Hero of Faith, (Ilesa, Haastrup Press, 1993), P. 3.

20. E.A. Ademowo, "The Growth of The Apostolic Church in Ijesaland, 1930-1990". An M.A. thesis submitted to the Department of Religious Studies, Obafemi Awolowo University, Ile-Ife, Nigeria, 1997, P. 63.

21. Ibid. P. 64.

22. C. Ekundayo, Itan Igbesi ati Ise Iranse Josefu Ayo Babalola, 1904-1959, (Ibadan, United Christian Publications, 2004), pp. 16-20.

23. C.D. Oshun, "Origin of Christ... P. 13.

24. D. Ayegboyin \& S.A. Ishola, P. 74.

25. E.H.L. Olusheye, P. 17.

26. S.G.A. Adegboyega, P. 30.

27. D. Ayegboyin \& S.A. Ishola, P. 75.

28. Ibid. P. 75 .

29. Ibid. P. 76.

30. S.I. Ogunsakin - Fabarebo \& O. Arowolo (eds.), Foundation Themes in Religion, (Ondo, Don Bosco Publishing Company, 2001), P. 134.

31. B.P. Clarke, West Africa and Christianity, (London, Arnold Press, 1986), PP. 167-169.

32. D. Ayegboyin \& S.A. Ishola, P. 77.

33. Ibid. P. 77.

34. Ibid. P. 77.

35. C.O. Oshun, "The Pentecostal Perspective of the Christ Apostolic Church", in ORITA: Ibadan Journal of Religious Studies, Vol. 15, No. 2, (December, 1983), pp. 105-114.

36. S.B. Mala, "The Christ Apostolic Church: Its History, Beliefs and Organization”, Faith Order Paper no. 79. The Ecumenical Review, Vol. 28, No 4 (October, 1976), pp. 418428.

37. J.A. Alokan, Idasile Ijo Apostolic ni Efon-Alaaye Ekiti, (Ibadan, Caxton Press, 1975), pp. 18-21; I.O. Eyebiokin, Igbedide Aposteli Joseph Ayo Babalola Pelu Ibere ati Idagbasoke Ijo C.A.C ni Ilu Ado-Ekiti, (Ado-Ekiti, Greenline Publishers Limited, 2004), P. 20ff. 